Klaudia Chalczyńska, Artur Zaręba

Katedra Filologii Słowiańskiej

Uniwersytet Łódzki

http://dx.doi.org/10.18778/8088-249-2.24

\title{
OKREŚLENIA MIGRANTÓW I ICH NACECHOWANIE NA POLSKICH, BUŁGARSKICH I SŁOWEŃSKICH INTERNETOWYCH PORTALACH INFORMACYJNYCH
}

Wielka migracja ludności z Bliskiego Wschodu i Afryki Północnej do krajów Unii Europejskiej jest bez wątpienia jednym z największych zagadnień politycznych ostatnich lat. Od początku lata 2015 świat zaczęło obiegać coraz więcej informacji o tysiącach ludzi próbujących dostać się drogą morską i lądową do państw Wspólnoty Europejskiej. Wojna domowa w Syrii, powstanie i działalność tzw. Państwa Islamskiego jak również destabilizacja większości państw objętych tzw. arabską wiosną doprowadziły do fali migracji o ogromnej skali, największej w Europie od czasów II wojny światowej.

Według Wysokiego Komisarza Narodów Zjednoczonych do spraw Uchodźców (UNHCR),tylko w 2015 r. przez Morze Śródziemne na Stary Kontynent przedostało się ponad milion osób ${ }^{1}$. Sprawa migrantów nie pozostała bez echa w światowych i europejskich mediach, które niemalże codziennie donoszą o dzialaniach państw europejskich, sytuacji ludzi chcących przedostać się do państw członkowskich Unii Europejskiej, incydentach i wypadkach z ich udziałem.

Celem tego artykułu jest zestawienie określeń ludności przybywającej do Europy $\mathrm{w}$ doniesieniach prasowych oraz porównanie nacechowania tych określeń w obrębie trzech badanych języków słowiańskich - bułgarskiego, polskiego i słoweńskiego. Przedmiotem analizy jest również odpowiedź na pytanie, czy któreś z wyekscerpowanych określeń poprzez konsekwentne i celowe używanie nabrało dodatkowego znaczenia, wykraczającego poza słownikowe definicje. Równie ważnym zadaniem jest zaobserwowanie, czy tytuły, reprezentujące odrębne nurty ideologiczne, posługują się tymi samymi określeniami migrantów, czy też preferencje polityczne wpływają na wybór form leksykalnych.

Wpływ języka na sposób myślenia człowieka jest tematem szeroko omówionym w literaturze przedmiotu. Nie jest celem niniejszego artykułu rozważanie

${ }^{1}$ UNHCR <http://data.unhcr.org/mediterranean/regional.php> (22.03.2016). 
teoretyczne na temat relacji pomiędzy językiem a procesami myślowymi, podkreślić warto jedynie, że wspomniany związek istnieje, o czym mówi hipoteza Sapira-Whorfa:

Struktury językowe, warunkując postrzeganie, klasyfikowanie i sposoby ujmowania rzeczywistości przez człowieka, wpływają tym samym na jego stan świadomości i cechy myślenia o rzeczywistości. W samym języku zawarty jest, do pewnego stopnia, obraz rzeczywistości. [Pacholski, Słaboń 2001: 58]

Sami dziennikarze wydają się świadomi wpływu języka na postrzeganie świata. Świadczyć o tym może fakt, że w sierpniu 2015 r. arabska telewizja Al-Jazeera zdecydowała, że nie będzie używać określenia migrant w stosunku do ludności przybywającej do granic Unii Europejskiej - zdaniem redakcji jest to określenie krzywdzące, przedstawiające uciekinierów z krajów Bliskiego Wschodu i Afryki Północnej w złym świetle.

Źródłem materiału do niniejszej pracy były artykuły dotyczące kryzysu migracyjnego $\mathrm{z}$ wybranych bułgarskich, polskich i słoweńskich portali informacyjnych, reprezentujących różne nurty ideologiczne: lewicowo-liberalny, centrowy i narodowo-konserwatywny. Dla odpowiednich języków były to kolejno portale:

- bułgarskie: „Земя”, „Труд”, „Стандарт”, „Атака”;

- polskie: „Gazeta Polska/Gazeta Polska Codziennie”, Rp.pl, „Gazeta Wyborcza”, „Dziennik Opinii”;

- słoweńskie: „Mladina”, „Delo”, „Reporter”, „Demokracija”.

W tym miejscu należy zaznaczyć, że o ile prasę polską i słoweńską cechuje wyraźny podział na lewicowo-liberalną i narodowo-konserwatywną, o tyle w Bułgarii zróżnicowanie to nie jest aż tak wyraźne i czytelnicy często nie są w stanie zdefiniować nurtu, reprezentowanego przez poszczególne portale i periodyki. Wynika to m.in. z mniejszej polaryzacji społeczeństwa oraz częstych zmian całych zespołów redakcyjnych, przechodzących $\mathrm{z}$ jednego tytułu do drugiego [Nowosad 2008: 408-409].

Krótka typologia prasoznawcza poszczególnych tytułów wygląda następująco:

Rp.pl - portal związany z dziennikiem „Rzeczpospolita”, ukazującym się od 1982 r., nawiązującym do dziennika o tym samym tytule, wydawanego w latach 1920-1934. Obecnie średni nakład wydania drukowanego wynosi 93920 egzemplarzy. Od 2011 r. właścicielem tytułu jest grupa Gremi Media, należąca do biznesmena Grzegorza Hajdarowicza.

Gazeta Polska/Gazeta Polska Codziennie - portal związany z tygodnikiem „Gazeta Polska” (wychodzącym od 1993 r., o średnim nakładzie 134694 egzemplarzy), dziennikiem „Gazeta Polska Codziennie” (od 2011 r., średni nakład 100000 egzemplarzy) i miesięcznikiem „Nowe Państwo”, który od 2009 r. ukazuje się jako „Niezależna Gazeta Polska - Nowe Państwo” (wydawana od 1994 r., 
średni nakład 25000 egzemplarzy). Portal internetowy i wskazane wydawnictwa należą do spółki Niezależne Wydawnictwo Polskie.

Gazeta.pl - działający od 2001 r. portal informacyjny, należący do spółki Agora SA. Jest powiązany z dziennikiem „Gazeta Wyborcza”, ukazującym się od 1989 r. Obecny nakład to ok. 240000 egzemplarzy.

Dziennik Opinii - powstały w 2012 r. portal informacyjny, należący do Stowarzyszenia im. Stanisława Brzozowskiego, do którego należy również ukazujący się od 2002 r. kwartalnik „Krytyka Polityczna”, z nakładem 6500 egzemplarzy.

Земя - portal związany z dziennikiem o tym samym tytule, wychodzącym od 1990 r. i będącym kontynuantem dzienników „Закооперативно земеделие” (1951-1958) і „Кооперативно семо” (1958-1990). Obecnie ukazuje się od poniedziałku do piątku w nakładzie 8000 sztuk. Jego wydawcą jest spółka „Коопмедия”, związana z Centralnym Związkiem Spółdzielczym (Централен кооперативен съюз).

Tpya - portal związany z dziennikiem o tym samym tytule. „TpyA” to najstarszy dziennik w Bułgarii (ukazuje się od 1936 r.), posiadający największy nakład spośród wszystkich dzienników (49 800 egzemplarzy od poniedziałku do piątku i 72100 w soboty). Należy do „Вестникарска група Бъмгария”, największego wydawcy periodyków w Bułgarii.

Стандарт - portal związany z dziennikiem o tym samym tytule, ukazującym się od 1992 r. w nakładzie ok. 35000 egzemplarzy (poniedziałek-piątek) i 70 000-100 000 egzemplarzy (sobota-niedziela). Większa część własności $(65,5 \%)$ należy do adwokata i biznesmena Todora Batkowa. Początkowo portal publikował jedynie artykuły, które ukazywały się w wersji drukowanej gazety, od 2008 r. przekształcił się jednak w pełnoprawny portal informacyjny publikujący wiadomości całodobowo.

Атака - portal związany ze skrajnie prawicową, populistyczną partią o tej samej nazwie, będący internetowym rozwinięciem drukowanego dziennika o tym samym tytule. Wydanie papierowe gazety ukazuje się od $2005 \mathrm{r}$. w nieregularnym nakładzie oscylującym od 6000 do 15000.

Mladina.si - słoweński portal informacyjny istniejący od 2000 r., który w dużym stopniu stanowi archiwum artykułów publikowanych w tygodniku „Mladina”, istniejącym od $1920 \mathrm{r}$. i ukazującym się w nakładzie 20000 egzemplarzy.

Delo.si - portal informacyjny związany z dziennikiem „Delo”, który powstał w 1959 r. Wydawany jest w nakładzie około 40000 egzemplarzy i dociera do ponad 100000 Słoweńców.

Reporter.si - portal informacyjny powiązany z tygodnikiem „Reporter”, wychodzącym w nakładzie 15000 egzemplarzy. Portal istnieje od roku 2008 i należy do wydawnictwa Prava Smer.

Demokracija.si - powiązany z tygodnikiem „Demokracija”, należącym do przedsiębiorstwa Nova obzorja. Jest wydawany od 1996 r. i należy do wydawnictwa Nova Obzorja. 
Zebrany materiał pokazuje, że do najczęściej stosowanych określeń we wszystkich trzech językach należą wyrazy:uchodźca (bg. бежанеu, słow.begunec), imigrant (bg. имигрант, słow. imigrant) oraz migrant (bg. мигрант, słow. migrant).Słowniki definiują te jednostki leksykalne w następujący sposób:

Uniwersalny stownik jezzkk polskiego [USJP]:

Migrant - socjol. Osoba migrująca.

Uchodźca - książk. Ten, kto opuścił własny kraj z przyczyn ekonomicznych, politycznych lub religijnych; emigrant, wychodźca.

Imigrant - urz. Cudzoziemiec, który osiedlił się w jakimś kraju; osiedleniec.

Речник на думите в българския език [RDBE]:

Мигрант - Аице, което се преселва от еАна Атржава в Аруга; заселник, преселник.

Бежанец - мн. бежанцй, м. Човек, който е напуснал родното си място поради преследване, войни, размирици и Ар. обстоятелства.

Имигрант - мн. имигра̀нти, м. Човек, заселен за постоянно в чужАа страна.

Slovar slovenskega knjižnega jezika [SSKJ]:

Migrant - kdor spreminja stalno ali začasno bivališče, zlasti iz gospodarskih vzrokov.

Begunec - 1. kdor (z)beži pred nevarnostijo ali neprijetnostijo. 2. kdor se izseli v tujino iz političnih vzrokov, emigrant.

Imigrant - knjiž. redko: priseljenec.

Jak wynika $\mathrm{z}$ przytoczonych definicji, wyraz migrant jest hiperonimem dla pozostałych i oznacza każdego człowieka, który zmienia swoje miejsce zamieszkania. Jedynie w słowniku słoweńskim wskazany jest ekonomiczny aspekt migracji, ujęty jednak jako „częsty”, a więc nie będący warunkiem koniecznym. Słowo imigrant definiowane jest zgodnie jako osoba osiedlająca się w kraju innym niż ten, z którego pochodzi. Uchodźca zaś zawiera w swojej definicji określone przyczyny przesiedlania się danej osoby - ekonomiczne, polityczne, religijne, wojny czy prześladowania.

Tabele 1-3 zawierają ilościowe zestawienie określeń migrant-imigrantuchodźca, użytych w artykułach na portalach polskich, bułgarskich i słoweńskich.

Tabela 1. Zestawienie ilościowe określeń migrantów w polskich portalach informacyjnych

\begin{tabular}{|l|c|c|c|c|c|}
\hline & Migrant & Imigrant & Uchodźca & Pozostałe & Razem \\
\hline „Gazeta Polska” & 0 & 50 & 20 & 5 & 75 \\
\hline Rp.pl & 2 & 50 & 43 & 19 & 114 \\
\hline Gazeta.pl & 0 & 15 & 71 & 26 & 115 \\
\hline „Dziennik Opinii” & 3 & 13 & 82 & 13 & 111 \\
\hline
\end{tabular}


W materiale polskim widać zarysowującą się tendecję do tworzenia opozycji imigrant::uchodźca. Narodowo-konserwatywna „Gazeta Polska” preferuje formę imigrant, aczkolwiek określenie uchodźca bywa z nią używane zamiennie, jak również $\mathrm{w}$ formach łączonych (imigranci i uchodźcy). Na centroprawicowym Rp.pl obydwie nazwy stosowane są absolutnie wymiennie. Na portalach centrolewicowym (Gazeta.pl) iliberalno-lewicowym („Dziennik Opinii”) zdecydowanie przeważa stosowanie formy uchodźca. Co ciekawe, hiperonim migrant praktycznie nie występuje.Do pozostałych określeń wykorzystywanych we wszystkich badanych witrynach należały wyrazy takie jak:przybysze, cudzoziemcy, muzutmanie.

Tabela 2. Zestawienie ilościowe określeń migrantów w bułgarskich portalach informacyjnych

\begin{tabular}{|l|c|c|c|c|c|}
\hline & Мигрант & Имигрант & Бежанец & Pozostałe & Razem \\
\hline „Атака” & 24 & 41 & 11 & 27 & 103 \\
\hline „Труд” & 14 & 5 & 35 & 13 & 67 \\
\hline „Стандарт” & 43 & 4 & 42 & 16 & 105 \\
\hline „Земя” & 21 & 1 & 24 & 35 & 81 \\
\hline
\end{tabular}

W materiale bułgarskim we wszystkich tytułach niezależnie od ich przynależności do określonego nurtu ideologicznego określenia мигрант і бежанец używane są wymiennie. We wszystkich przypadkach poza narodowo-konserwatywnym portalem „Атака” nazwa имигрант pojawia się w pojedynczych przypadkach, na tym jednym portalu jest zaś formą używaną najczęściej. Świadczy to o chęci podkreślenia ekonomicznych przyczyn migracji obywateli państw Bliskiego Wschodu i Afryki Północnej do Europy, co powoduje, że z tym określeniem często łączone są takie przymiotniki jak нелегален сzу икономически. Ponadto, podobnie jak w polskich źródłach, użyto innych wyrazów m. in. бегълци, чужденции.

Tabela 3. Zestawienie ilościowe określeń migrantów w słoweńskich portalach informacyjnych

\begin{tabular}{|l|c|c|c|c|c|}
\hline & Migrant & Imigrant & Begunec & Pozostałe & Razem \\
\hline „Reporter” & 47 & 0 & 9 & 29 & 85 \\
\hline „Demokracija” & 36 & 0 & 16 & 0 & 52 \\
\hline „Delo” & 25 & 0 & 112 & 21 & 158 \\
\hline „Mladina” & 4 & 0 & 119 & 15 & 138 \\
\hline
\end{tabular}

W przypadku materiału słoweńskiego najwyraźniejszą tendencją jest nieobecność formy imigrant. Nazwy migrant i begunec tworzą wyraźną opozycję, a ich sto- 
sowanie jest powiązane $\mathrm{z}$ nurtem ideologicznym, reprezentowanym przez dany portal. Na portalach prawicowych przeważa używanie form migrant, podczas gdy na portalach lewicowych zdecydowanie preferowana jest forma begunec.

$\mathrm{Z}$ powyższego zestawienia wynika, że $\mathrm{w}$ języku polskim nazwy imigrant i uchodźca stosowane są $\mathrm{w}$ dwójnasób: o ile na portalach prawicowych są często używane zamiennie, o tyle na portalach lewicowych zdecydowanie przeważa użycie drugiej z tych form, natomiast wyraz migrant stosowany jest bardzo rzadko. W językach bułgarskim i słoweńskim to forma imigrant będzie używana sporadycznie, za wyjątkiem narodowo-konserwatywnego bułgarskiego portalu „Атака”, gdzie używana jest celowo i obciążona jest nacechowaniem negatywnym. Jest to jednak odosobniony wyjątek na tle pozostałych bułgarskich portali, które całkowicie zamiennie stosują określenia migrant i uchodźca. W materiale słoweńskim najwyraźniej zarysowuje się podział na portale narodowo-konserwatywne i liberalno-lewicowe, które będą wyraźnie preferować pierwszą albo drugą $\mathrm{z}$ wymienionych wyżej form.

Powyższe dane wskazują, że w przypadku polskich i słoweńskich portali wybór określenia jest wyraźnie uzależniony od nurtu ideologicznego, reprezentowanego przez poszczególne periodyki. Bułgarskie portale używają określeń całkowicie wymiennie. Można więc przypuszczać, że różnice zarysowują się tam, gdzie podział na poszczególne nurty ideologiczne jest wyraźniejszy i łatwiejszy do identyfikacji dla czytelnika (przypadki portali polskich i słoweńskich).Podczas gdy w Bułgarii, gdzie większość z badanych portali nie jest aż tak wyraźnie powiązana z konkretnymi nurtami ideologicznymi, nie ma większych różnić w wyborze form leksykalnych.

\section{LITERATURA}

\section{Słowniki}

[RDBE] - Речник на думите в българския език, http://rechnik.info/.

[SSKJ] - Slovar slovenskega knjižnega jezika, http://www.fran.si/130/sskj-slovar-slovenskega-knjiznega-jezika, Inštitut za slovenski jezik Frana Ramovša ZRC SAZU.

[USJP] - Uniwersalny stownik jezyka polskiego PWN, http://usjp.pwn.pl/.

\section{Literatura przedmiotu}

[Nowosad 2008] - A. Nowosad, Wtadza i media w Butgarii, Wydawnictwo Uniwersytetu Jagiellońskiego, Kraków.

[Pacholski, Słaboń 2001] - M. Pacholski, A. Słaboń, Stownik pojęć socjologicznych, Wydawnictwo Akademii Ekonomicznej w Krakowie, Kraków.

[Sapir 1978] - E. Sapir, Kultura, język, osobowość. Wybrane eseje, Państwowy Instytut Wydawniczy, Warszawa.

[Whorf 2002] - B. L. Whorf, Język, myśl i rzeczywistość, Wydawnictwo KR, Warszawa. 
Klaudia Chalczyńska, Artur Zaręba

\title{
WORDS DESCRIBING MIGRANTS AND THEIR EMOTIONAL VALUE ON THE BASIS OF POLISH, BULGARIAN AND SLOVENIAN ONLINE PORTALS
}

\author{
(Summary)
}

In our paper we present the results of research concerning nouns used to describe people migrating from the Middle East and North Africa during last year (2015) on Polish, Bulgarian and Slovenian news websites. The collected data shows, that words migrant, immigrant and refugee are the majority of all nouns used. In Polish sources the main two words used to describe the migrants are: immigrant and refugee, which are used interchangeably in national-conservative sites, while liberal-left orientated portals prefer the second word. In Bulgarian and Slovenian sources the world immigrant is used extremely rarely; the only exception is Bulgarian right-wing conservative website Атака. The difference between Bulgarian and Slovenian lies in the division for national-conservative and left-wing liberal titles; which do not differ in the Bulgarian part of the data (with only one exception mentioned above), while on Slovenian websites this division is evident. 